DOI: https://doi.org/10.47405/mjssh.v5i4.389

\begin{tabular}{|c|c|}
\hline 4 & Malaysian Journal of Social Sciences and Humanities (MJSSH) \\
\hline $\begin{array}{l}\text { Malaysian Journal of } \\
\text { Social sciences and }\end{array}$ & Volume 5, Issue 4, April 2020 \\
\hline (MJ-SSH) & e-ISSN : 2504-8562 \\
\hline & $\begin{array}{l}\text { Journal home page: } \\
\text { www.msocialsciences.com }\end{array}$ \\
\hline
\end{tabular}

\title{
Kompetensi Sosial dan Emosional (KSE) Untuk Pengajaran Matematik Sekolah Menengah di Malaysia
}

\author{
Radin Muhd Imaduddin Bin Radin Abdul Halim¹, Ruhizan Binti Mohammad Yasin1, Nik Mohd \\ Rahimi Nik Yusoff ${ }^{1}$ \\ 1Fakulti Pendidikan, Universiti Kebangsaan Malaysia (UKM)
}

Correspondence: Radin Muhd Imaduddin Bin Radin Abdul Halim (radin.muhd@live.com)

\begin{abstract}
Abstrak
Kepentingan penguasaan kemahiran sosial dan emosional (KSE) dikatakan merupakan teras kepada kejayaan masa hadapan murid. Perubahan emosi sangat berkait rapat dengan fenomena sosial dan ini termasuklah dalam konteks pembelajaran dalam bilik darjah, dalam ekosistem sekolah dan di luar ekosistem sekolah. Pembelajaran yang memaknakan KSE dipanggil pembelajaran sosial dan emosional (PSE). Impak keberkesanan PSE dikatakan membantu murid sehingga dewasa daripada aspek kesejahteraan murid seperti pendidikan, pekerjaan dan penghasilan sosial. Walau bagaimanapun, dalam konteks kurikulum kebangsaan, tidak banyak kajian berkaitan PSE khususnya dalam pendidikan Matematik. Kertas ini bertujuan mengenal pasti dan mengesahkan komponen KSE yang sesuai dijalankan dalam persekitaran sekolah menengah di Malaysia bagi pengajaran matematik. Kajian ini menggunakan kaedah kajian literatur sebagai proses membandingkan beberapa model, mengenal pasti komponen KSE dalam model tersebut, dan seterusnya menggunakan kaedah fuzzy delphi (KFD) untuk mendapatkan pengesahan melalui kesepakatan sebelas orang pakar daripada pelbagai bidang. Dapatan menunjukkan bahawa kesemua pakar bersetuju dengan kesemua komponen kompetensi yang dicadangkan iaitu kompetensi kesedaran kendiri, pengurusan diri, kesedaran sosial, kemahiran berhubungan, tanggungjawab dalam membuat keputusan, sikap berorientasikan matlamat, tanggungjawab peribadi dan berfikiran optimistik. Komponen KSE ini penting sebagai asas dalam membangunkan intervensi berkaitan meningkatkan kemahiran sosial dan emosional dalam konteks pengajaran matematik sekolah menengah di Malaysia. Seterusnya, menunjukkan bahawa KSE boleh diterapkan dalam pengajaran matematik dan memberikan impak kepada kesejahteraan masa hadapan murid.
\end{abstract}

Kata kunci: emosional, fuzzy delphi, kompetensi, sosial

\section{Social and Emotional Competence (SEC) for Mathematic Secondary Classroom in Malaysia}

\begin{abstract}
The importance of mastering social and emotional skills (SEC) is said to be at the heart of student success. Emotional change is closely related to social phenomena and this includes the context of classroom learning, within the school ecosystem and outside of the school ecosystem. Learning that promotes SEC is called the social and emotional learning (SEL). The impact of SEL effectiveness is said to help pupils to adulthood in aspects of student well-being such as education, employment and social life. However, in the context of the national curriculum, there are not many studies related to
\end{abstract}


SELs especially in Mathematics education. This paper aims to identify and validate the components of SECs that are appropriate for the Malaysian secondary school environment for mathematics teaching. The study used the literature review method as the process of comparing several models, identifying SEC components in the model, and then using the fuzzy delphi (FDM) method to obtain validation through the agreement of eleven experts from various fields. The findings indicate that all experts agree on all components of the proposed competencies namely self-awareness competence, self-management, social awareness, communication skills, decision-making responsibility, goal-oriented attitude, personal responsibility and optimistic thinking. These component of SECs are important as a basis for developing interventions aimed at improving social and emotional skills in the context of secondary school mathematics teaching in Malaysia. Furthermore, it shows that SEC can be applied in mathematics teaching and have an impact on students' future well-being.

Keywords: emotional, fuzzy delphi, competence, social

\section{Pengenalan}

Persoalan kepintaran sosial pernah disentuh oleh Edward Thorndike pada awal 1920-an yang menerangkan bahawa kepintaran sosial ini memandu arah seseorang untuk memahami personaliti dan tingkah laku sosial orang lain seterusnya menjadi kunci kepada kejayaan seseorang termasuk daripada aspek motivasi, kepuasan bekerja, produktiviti dan lain-lain berkaitan interaksi sosial (Noriah, 2019). Idea kepintaran sosial Thordike ini dikembangkan Gagné (1998) dalam teori kepelbagaian kepintaran yang mana di antaranya, adalah kepintaran interpersonal dan intrapersonal, justeru memperincikan dan melibatkan sekali kepintaran emosi.

Goleman (1995) pula, menerusi bukunya 'Emotional Intelligence, why it can matter more than IQ' memecahkan fokus masyarakat terhadap kepentingan kemahiran sosial dan emosional mengatasi kecerdasan intelektual (IQ). Beliau menegaskan bahawa penguasaan kemahiran sosial dan emosional merupakan teras kepada kejayaan masa hadapan anak-anak di tempat kerja kelak (D. Goleman, 1998; Marchesi et al., 2012). Goleman menetapkan lima prinsip asas yang mencerminkan kecerdasan emosi (EQ) seperti berikut: (1) Kesedaran kendiri, (2) Pengurusan emosi (3) Motivasi kendiri (4) Empati (5) Kemahiran sosial. Lantas, idea dan konsep EQ Goleman diketengahkan pula dalam konteks pembelajaran sosial dan emosional (PSE) oleh pelbagai tokoh (Cohen 1999 \& 2001; M. Elias 2016; M. J. Elias 2006; M. J. Elias et al. 1997; Schonert-Reichl \& Hymel 2007; Zins \& Elias 2006).

Daripada aspek sosiologi pula, Gordon (1990) menjelaskan bahawa emosi perlu difahami dalam konteks struktur sosial dan kandungan sosial yang pelbagai serta dalam persekitaran budaya yang unik. Maka, perubahan emosi sangat berkait rapat pula dengan fenomena sosial dan ini sudah tentu termasuk dalam konteks pembelajaran (Barbalet, 1998; Bericat, 2016; Stets et al., 2006). Kepintaran, kemahiran atau kompetensi ini perlu diamalkan sama ada dalam bilik darjah, di dalam ekosistem sekolah, dan juga di luar ekosistem sekolah.

Dalam konteks penerapan PSE di pelbagai negara, OECD (2015) mengeluarkan laporan kajian longitudinal di sembilan buah negara, yang mana mengesahkan impak dan kepentingan PSE dalam membantu individu dalam peningkatan domain pendidikan, pasaran pekerjaan, dan penghasilan sosial. Negara yang dilaporkan adalah Belgium, Kanada, Korea Selatan, New Zealand, Norway, Sweden, Switzerland, United Kingdom dan Amerika Syarikat. Sebelum itu, Fundacion Botin (2013) juga mengeluarkan laporan kualitatif kajian-kajian kes berkaitan PSE di negara Argentina, Austria, Israel, Norway dan Afrika Selatan.

Walau bagaimanapun, menurut Ismail, Rahim, dan Yusoff (2013), kajian berkaitan PSE dalam konteks Malaysia masih berkurangan. Daripada aspek pengurusan diri dan sikap bertanggungjawab yang membawa kepada implikasi soal disiplin dan iklim persekolahan, Lee, Yeo, dan Hadijah (2015) menyatakan bahawa kajian berkaitan isu disiplin murid di Malaysia banyak berkisar tentang mengenal pasti sikap positif dan negatif murid, serta menentukan tahap permasalahan tersebut dan faktor yang 
menyebabkannya. Beliau seterusnya mencadangkan PSE sebagai pendekatan yang berpotensi dalam mengurangkan sikap negatif, meningkatkan sikap yang dihasratkan, serta mempromosikan pembangunan yang positif termasuk penerapan PSE dalam bilik darjah.

Kepentingan PSE dan KSE diperkukuhkan lagi dengan kajian Shanmugasundaram \& Mohamad (2011) yang bersetuju bahawa kemenjadian murid dalam konteks keseimbangan emosi seperti yang dieksplisitkan dalam Falsafah Pendidikan Kebangsaan sering kali tidak menjadi tumpuan disebabkan masyarakat meletakkan keutamaan dan pemberatan keterlaluan dalam pencapaian markah peperiksaan. Hal ini penting diangkat disebabkan kes-kes salah laku murid, termasuk kes buli, penyalahgunaan dadah, dan isu kesihatan mental di Malaysia terus-menerus membimbangkan (Berita Harian 2018; Parlimen Malaysia, 2018; dan Sinar Online, 2017; Agensi Anti Dadah Kebangsaan 2018; Astro Awani 2018; Institut Kesihatan Umum 2018 ).

Dalam konteks penerapan PSE di Malaysia, penerapan PSE dalam bilik darjah tidak menunjukkan hasil yang memberangsangkan disebabkan reka bentuk PSE dalam kurikulum tidak menjadi keutamaan, di samping perancangan untuk pelaksanaannya tidak diberikan perhatian sewajarnya (Lee et al., 2015). Walaupun usaha penerapan PSE memang sudah terdapat dalam kurikulum kebangsaan yang mula dilaksanakan pada tahun 2017 (KSSR Semakan 2017) dan diterapkan secara langsung, namun hanya terhad dalam mata pelajaran Pendidikan Islam, Pendidikan Moral dan Pendidikan Kesihatan, serta dalam Pendidikan Global, iaitu salah satu daripada elemen merentas kurikulum. Oleh sebab itu, keperluan untuk memperkaya komponen dan elemen PSE dalam kurikulum menjadi sangat penting dan signifikan, yang mana kajian ini menghasratkan untuk menerapkan PSE dalam mata pelajaran matematik sekolah menengah, dengan mengenal pasti kompetensi sosial dan emosional yang bersesuaian dalam konteks mata pelajaran ini.

Dalam kajian ini, konteks pembelajaran sosial dan emosional (PSE) merujuk kepada proses pengajaran dan pembelajaran mata pelajaran matematik yang mana murid dan guru belajar untuk memahami dan mengurus emosi, mengekalkan hubungan yang positif, merasai dan menunjukkan empati dengan orang lain, menentukan dan berusaha untuk mencapai tujuan positif, serta membuat keputusan yang bertanggungjawab (CASEL, 2017; Charles A. Dana Center \& CASEL, 2016; O'Conner et al., 2017). Kompetensi yang diupayakan dalam pembelajaran ini memaknakan kompetensi sosial dan emosional. Kewujudan kompetensi ini diharapkan dapat menjadi panduan kepada guru untuk menerapkan dan melengkapkan kekurangan elemen ini dalam diri murid (Institute for Public Health, 2018; Lee et al., 2015; Madlan et al., 2017). Maka, artikel ini berhasrat untuk menjawab persoalan kajian, "Apakah komponen kompetensi sosial dan emosional (KSE) yang sesuai dijalankan dalam persekitaran sekolah menengah di Malaysia bagi pengajaran matematik berdasarkan kesepakatan pakar?”

\section{Metod Kajian}

Bagi mendapatkan komponen kompetensi sosial dan emosional (KSE) yang sesuai dijalankan dalam persekitaran sekolah menengah di Malaysia bagi pengajaran matematik, penyelidik perlu mengenal pasti komponen KSE berdasarkan model-model terdahulu. Ini dapat dilaksanakan melalui kaedah kajian literatur. Kemudian, item ini melalui proses pengesahan oleh panel pakar, justeru analisis kaedah fuzzy delphi digunakan. Perincian metodologi dipaparkan seperti berikut:

\section{Kaedah Kajian Literatur}

Collaborative For Academic, Social and Emotional Learning, atau ringkasnya CASEL, (2017) antara organisasi awal yang menekankan kepentingan PSE dan mengenengahkan kerangka PSE seperti dalam rajah di bawah: 


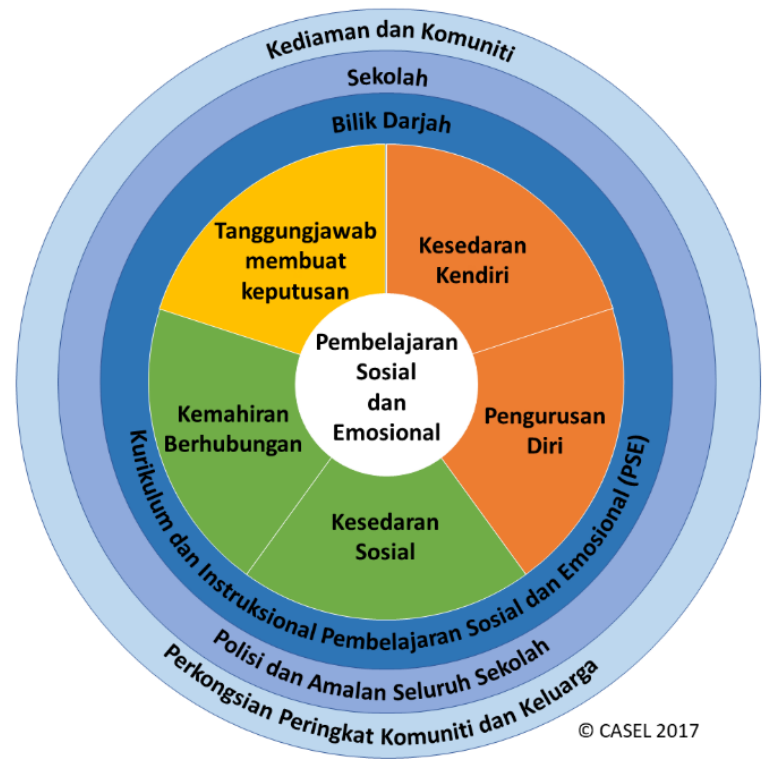

Rajah 1: Kerangka pembelajaran sosial dan emosional

Sumber: CASEL 2017

CASEL (2017) mengangkat lima nilai sebagai kompetensi dalam pembelajaran sosial dan emosional. CASEL melihat kepentingan dan impak PSE diukur melalui nilai atau kompetensi berikut, iaitu kesedaran kendiri, kesedaran sosial, pengurusan diri, kemahiran berhubungan, dan tanggungjawab dalam membuat keputusan. Walau bagaimanapun, Devereux Student Strengths Assessment, DESSA (2018) pula menambah tiga lagi nilai iaitu sikap berorientasikan matlamat, tanggungjawab personal, dan berfikiran optimistik. McClelland Center for Research and Innovation Hay Group, (2011) yang menerbitkan Emotional and Social Competency Inventory (ESCI) pula memberi fokus kepada empat nilai kebijaksanaan emosional, yang merangkumi kemahiran sosial (Boyatzis \& Goleman, 2017) sama seperti CASEL, kecuali tidak meletakkan nilai 'tanggungjawab dalam membuat keputusan' dalam kerangkanya. Model ESCI memetakan hubungan empat nilai kebijaksanaan emosi dengan perspektif 'kendiri' dan 'pihak lain' seperti dalam rajah 2.

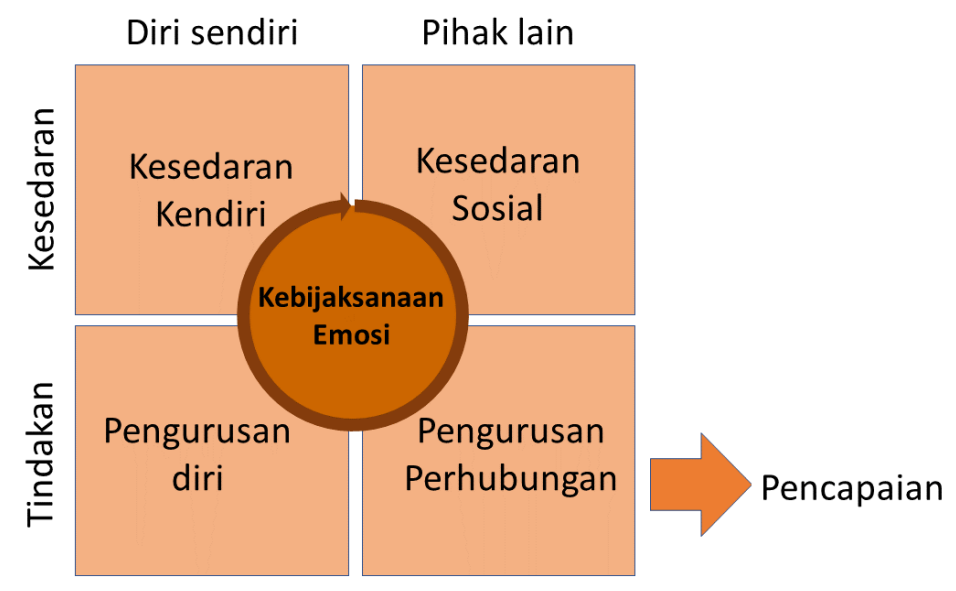

Rajah 2: Model ESCI

Sumber: L\&T direct and the McClelland Center for Research and Innovation Hay Group 2011

OECD (2018) pula menggunakan istilah 'kemahiran'. OECD memetakan struktur kemahiran sosial dan emosional kepada domain 'lima utama' (The 'big five' domain) berserta satu kemahiran majmuk yang membawa kepada 15 kemahiran sosial dan emosional keseluruhannya. Lima domain tersebut adalah 
DOI: https://doi.org/10.47405/mjssh.v5i4.389

pencapaian tugasan, pengawalan emosi, kolaboratif, keterbukaan, dan keterlibatan dengan pihak lain. Lima domain ini secara jelasnya berasaskan kepada "model lima (faktor) utama" personaliti (The Big Five) (John \& Srivastava, 1999).

Istilah yang digunakan dalam model The Big Five adalah keterbukaan dalam mencari pengalaman (Openness to experience), keberhematan/nurani (Conscientiousness), Ektraversi (Extraversion), kebersetujuan (Agreeableness), dan neuroticisme (Neuroticism). Akronim yang biasa digunakan untuk menyatakan model The Big Five ini adalah OCEAN. Justeru, yang membezakan model OECD dan model The Big Five adalah faktor 'pengawalan emosi' menggantikan 'neuroticism'. Model OECD ini akan digunakan dalam kajian penandaarasan antarabangsa, Study on Social and Emotional Skills (SSES) bermula tahun 2019. Kerangka model OECD seperti dalam rajah 3.

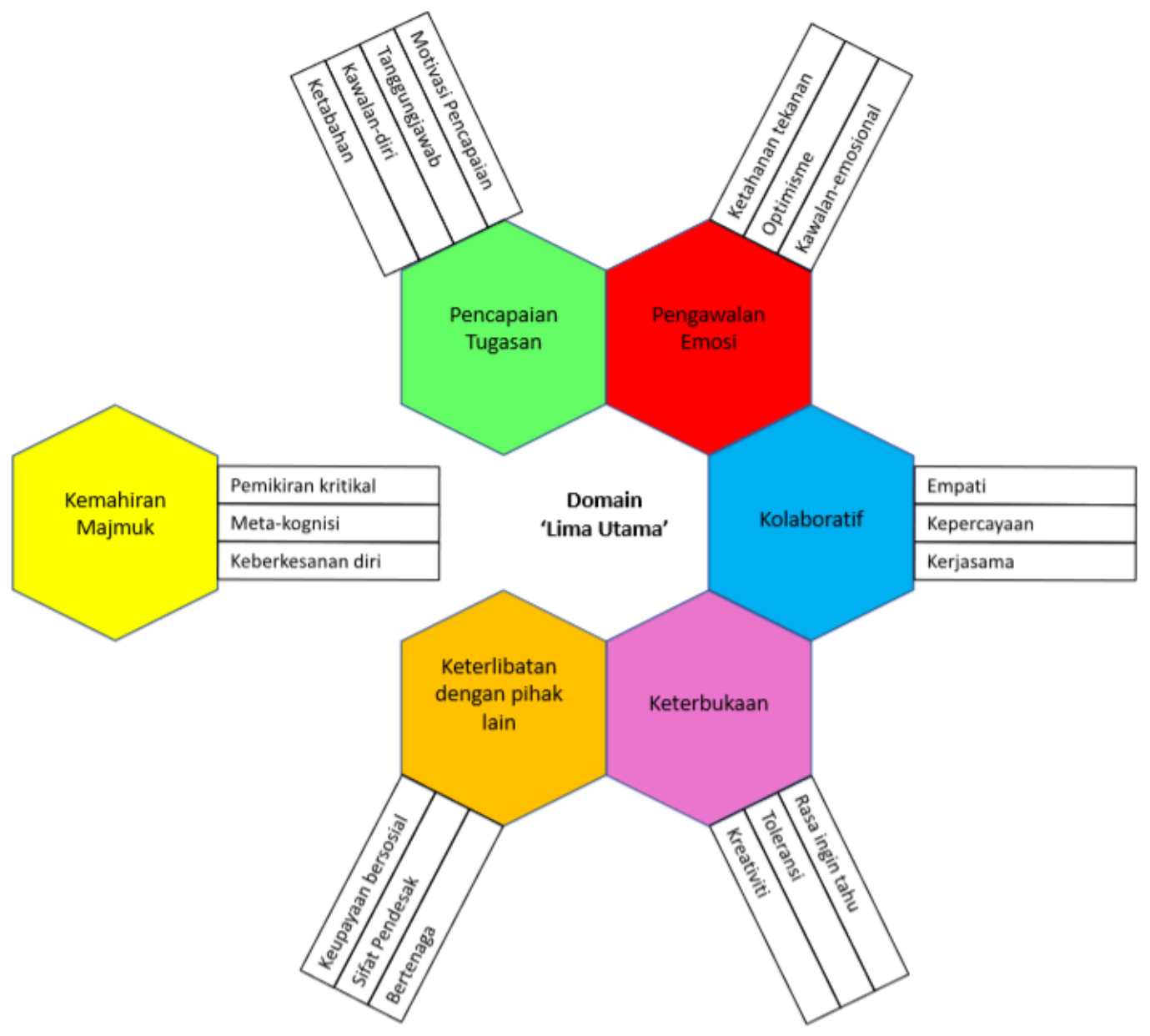

Rajah 3: Model "The Big Five" Study on Social and Emotional Skills (SSES)

Sumber: OECD 2018

Bagi kajian ini, item kompetensi sosial dan emosional diartikulasikan dan dirumuskan daripada model CASEL (2017), model DESSA (2018), model ESCI, (2011), model 'The Big Five' (1999) dan model OECD (2018). Nilai dan huraian ringkas bagi setiap kompetensi dipaparkan seperti dalam jadual 2.1. Kelapan-lapan kompetensi ini seterusnya dijadikan asas kepada kajian ini dan perlu melalui proses mendapatkan pengesahan daripada pakar-pakar dalam bidang yang berkenaan. Kompetensi tersebut adalah:
i. Kompetensi Kesedaran Kendiri
ii. Kompetensi Pengurusan diri
iii. Kompetensi Kesedaran Sosial 
Malaysian Journal of Social Sciences and Humanities (MJSSH), Volume 5, Issue 4, (page 41 - 55), 2020

DOI: https://doi.org/10.47405/mjssh.v5i4.389
iv. Kompetensi Kemahiran Berhubungan
v. Kompetensi Tanggungjawab dalam Membuat Keputusan
vi. Kompetensi Sikap Berorientasikan Matlamat
vii. Kompetensi Tanggungjawab Peribadi
viii. Kompetensi Berfikiran Optimistik

Jadual 1: Rumusan kompetensi sosial dan emosional (KSE) berserta ringkasan huraian dan item

\begin{tabular}{|c|c|c|}
\hline $\begin{array}{c}\text { Kompetensi / } \\
\text { Kemahiran }\end{array}$ & Ringkasan Huraian Dan Item & Rujukan \\
\hline $\begin{array}{ll}\text { Kesedaran Kendiri } \\
\text { - } \quad \text { Kesedaran kendiri } \\
\text { - } \quad \text { secara emosional. } \\
\text { - } \quad \text { Sifat ingin tahu } \\
\quad \text { Asertif }\end{array}$ & 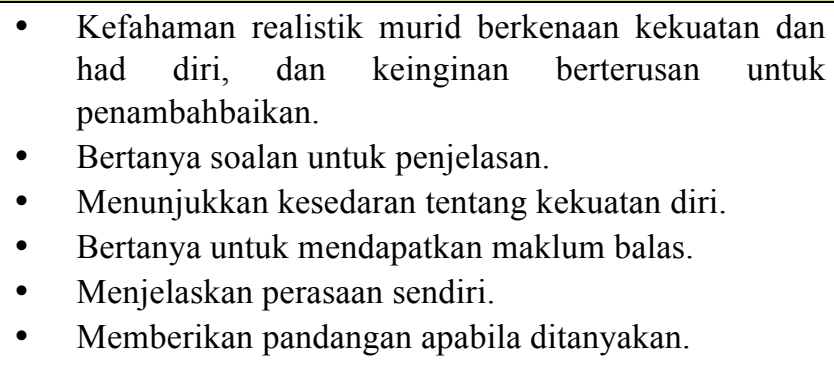 & $\begin{array}{l}\text { (CASEL, 2017) } \\
(\mathrm{DESSA}, 2018) \\
(\mathrm{ESCI}, 2011) \\
(\mathrm{OECD}, 2018)\end{array}$ \\
\hline $\begin{array}{l}\text { Pengurusan Diri } \\
\text { - } \quad \text { Pengurusan diri } \\
\text { secara emosional. } \\
\text { - } \text { Beriorientasikan } \\
\text { pencapaian. } \\
\text { - } \quad \text { Harapan positif } \\
\text { - } \quad \text { Tahan tekanan } \\
\text { - } \quad \text { Kawalan emosi }\end{array}$ & $\begin{array}{l}\text { - Kejayaan murid dalam mengawal emosi dan sikap } \\
\text { bagi menyelesaikan tugasan atau mengharungi situasi } \\
\text { baharu yang mencabar. } \\
\text { - } \quad \text { Memberikan perhatian. } \\
\text { - } \quad \text { Mekus kepada tugasan walaupun ada gangguan. } \\
\text { - } \quad \text { Berfikir sebelum bertindak. } \\
\text { - Tetap rasa tenang walaupun dicabar. }\end{array}$ & $\begin{array}{l}\text { (CASEL, 2017) } \\
(\mathrm{DESSA}, 2018) \\
(\mathrm{ESCI}, 2011) \\
(\mathrm{OECD}, 2018)\end{array}$ \\
\hline $\begin{array}{l}\text { Kesedaran Sosial } \\
\text { - } \quad \text { Empati } \\
\text { - } \quad \text { Kesedaran } \\
\text { berorganisasi } \\
\text { - } \quad \text { Kepercayaan } \\
\text { - } \quad \text { Kerjasama } \\
\text { - } \quad \text { Toleransi } \\
\text { - } \quad \text { Upaya Sosial }\end{array}$ & $\begin{array}{l}\text { - Kapasiti murid untuk berinteraksi dengan pihak lain } \\
\text { dengan rasa hormat terhadap idea dan sikap mereka, } \\
\text { mengenal pasti impak yang murid berikan kepada } \\
\text { pihak lain, serta bekerjasama dan bertoleransi dalam } \\
\text { situasi sosial. } \\
\text { Boleh bercampur-gaul dengan orang yang berbeza- } \\
\text { beza. } \\
\text { - Bertindak secara saling menghormati dalam situasi } \\
\text { - } \text { persaingan. } \\
\text { - Menghormati pandangan orang lain. } \\
\text { - } \text { Benyelesaikan sebarang perselisihan. }\end{array}$ & $\begin{array}{l}\text { (CASEL, 2017) } \\
(\mathrm{DESSA}, 2018) \\
(\mathrm{ESCI}, \quad 2011) \\
(\mathrm{OECD}, 2018)\end{array}$ \\
\hline $\begin{array}{l}\text { Kemahiran } \\
\text { Berhubungan } \\
\text { - Mempengaruhi } \\
\text { - } \quad \text { Melatih dan } \\
\text { membimbing } \\
\text { - Menguruskan } \\
\text { konflik } \\
\text { Pengurusan } \\
\text { menginspirasikan } \\
\text { Kerjasama } \\
\text { berpasukan. }\end{array}$ & $\begin{array}{l}\text { - Pencapaian berterusan murid berkaitan tindakan } \\
\text { murid yang boleh diterima secara sosial yang } \\
\text { mempromosikan dan mengekalkan perhubungan } \\
\text { yang positif dengan pihak lain. } \\
\text { - Memuji atau mengucapkan tahniah. } \\
\text { - Mengungkapkan rasa prihatin. } \\
\text { - Memberikan cadangan atau memohon sesuatu secara } \\
\text { beradab. } \\
\text { - Menawarkan untuk membantu. } \\
\text { Memberikan respon kepada perasaan yang } \\
\text { dicurahkan. }\end{array}$ & $\begin{array}{l}\text { (CASEL, 2017) } \\
(\mathrm{DESSA}, 2018) \\
(\mathrm{ESCI}, 2011)\end{array}$ \\
\hline
\end{tabular}


DOI: https://doi.org/10.47405/mjssh.v5i4.389

Tanggungjawab Dalam • Pendekatan murid dalam proses penyelesaian Membuat Keputusan masalah yang memerlukan murid menggunakan

- Kreatif pengalaman mereka pada masa lalu, pembelajaran

(CASEL, 2017)

(DESSA, 2018)

- Muhasabah diri dengan pihak lain, dan seterusnya berakauntabiliti

(OECD, 2018) dalam keputusan yang dibuat.

- Terima tanggungjawab yang diberikan.

- Menunjukkan pertimbangan yang baik.

- Belajar daripada pengalaman.

- Mengikut nasihat orang dewasa yang dipercayai.

- Memutuskan mana yang betul dan mana yang salah.

Sikap Berorientasikan Matlamat

- Berorientasikan pencapaian.

- Ketekunan

- Bertenaga

- Keberkesanan kendiri

\section{Tanggungjawab peribadi \\ - Bertanggungjawab dengan komitmen \\ - Kawalan kendiri \\ - Berdikari}

- Inisiatif murid dalam menyelesaikan tugasan dengan menunjukkan sikap tabah dalam tahap kesukaran yang berbeza-beza.

- Terus mencuba apabila menghadapi kegagalan.

- Terus mencari pengetahuan tambahan.

- Mengambil peranan aktif dalam pembelajaran.

- Mencari tugasan yang mencabar.

- Bekerja keras untuk tugasan dan projek.

- Kecenderungan murid untuk berhati-hati dan sikap boleh diharap murid dalam tindakan mereka memberikan sumbangan pada kerja-kerja berkumpulan atau secara kolektif.

- Menjaga barang peribadi dengan baik.

- Bersedia untuk urusan persekolahan.

- Melakukan tugasan tanpa perlu diperingatkan.

- Bekerja dalam masa yang ditetapkan.

- Menunjukkan ketelitian semasa menjalankan tugasan.

- $\quad$ Sikap murid berkaitan keyakinan, pengharapan, dan pemikiran positif terhadap diri murid sendiri, dan situasi kehidupan murid pada masa lalu, semasa dan masa hadapan.

- Membawa diri dengan keyakinan tinggi.

- Menyatakan perkara baik-baik tentang diri sendiri.

- Bercakap tentang perkara yang positif.

- Menyatakan perkara baik-baik tentang masa hadapan.

- Mengungkapkan harapan yang tinggi untuk diri sendiri.
(DESSA, 2018)

(OECD, 2018)

(DESSA, 2018)

(OECD, 2018)

(DESSA, 2018)

(OECD, 2018)
- Penghargaan

- Keterbukaan

- Set minda

- Berharap 
kurikulum matematik, dua orang daripada bidang inovasi dalam pendidikan, dan dua orang daripada bidang psikologi pendidikan.

Maka, proses utama adalah menyediakan instrumen soal selidik berdasarkan sorotan kajian. Kemudian, proses mendapatkan data dilakukan daripada pakar-pakar yang dilantik berdasarkan kriteria tertentu secara bersemuka seorang demi seorang. Pakar menjawab soal selidik yang disediakan dan pakar boleh bertanyakan soalan untuk menambah kefahaman berkaitan kandungan dalam setiap item. Tujuannya adalah untuk mendapatkan kesepakatan dalam kesetujuan bagi setiap komponen. Menurut kaedah fuzzy delphi, pakar dianggap bersepakat dan mencapai konsensus kesetujuan apabila memenuhi tiga syarat, iaitu apabila nilai skala fuzzy dalam unit threshold, $d \leq 0.2$ (Cheng \& Lin, 2002), apabila bilangan peratusan pakar yang bersetuju adalah sama atau melebihi 75\% (Chu \& Hwang, 2008), dan apabila nilai purata skor fuzzy melebihi atau sama dengan nilai 0.5 (Tang \& $\mathrm{Wu}, 2010$ ). Maka, untuk mendapatkan nilai threshold, semua pemboleh ubah linguistik ditukarkan kepada nilai penomboran segi tiga fuzzy (triangular fuzzy numbers). Dalam kajian ini, aras persetujuan atau aras kesesuaian bagi skala likert 7 mata seperti dalam jadual di bawah:

Jadual 2: Aras Persetujuan, atau Aras kesesuaian serta Skala Fuzzy bagi skala likert 7 mata

\begin{tabular}{|c|c|c|}
\hline \multicolumn{2}{|c|}{ Pemboleh ubah linguistik } & \multirow{2}{*}{ Skala Fuzzy } \\
\hline Aras persetujuan & Aras Kesesuaian & \\
\hline Teramat Setuju & Teramat Sesuai & $(0.9,1.0,1.0)$ \\
\hline Sangat Setuju & Sangat Sesuai & $(0.7,0.9,1.0)$ \\
\hline Setuju & Sesuai & $(0.5,0.7,0.9)$ \\
\hline Sederhana Setuju & Sederhana Sesuai & $(0.3,0.5,0.7)$ \\
\hline Tidak Setuju & Tidak Sesuai & $(0.1,0.3,0.5)$ \\
\hline Sangat Tidak Setuju & Sangat Tidak Sesuai & $(0.0,0.1,0.3)$ \\
\hline Teramat Tidak Setuju & Teramat Tidak Sesuai & $(0.0,0.0,0.1)$ \\
\hline
\end{tabular}

Sumber Rujukan: M. Jamil, Siraj, Hussin, Mat Noh, \& Sapar, (2017, p. 64)

Nilai threshold (d) ini dikira berdasarkan formula seperti di bawah, dengan nilai $m_{1}, m_{2}$ dan $m_{3}$ ialah purata nilai minimum, purata nilai paling munasabah, dan purata nilai maksimum dalam nilai penomboran segi tiga fuzzy, manakala nilai $n_{1}, n_{2}$ dan $n_{3}$ ialah nilai minimum, nilai paling munasabah, dan nilai maksimum pada skala fuzzy untuk setiap item respon pakar.

$$
d(\tilde{m}, \tilde{n})=\sqrt{\frac{1}{3}\left[\left(m_{1}-n_{1}\right)^{2}+\left(m_{2}-n_{2}\right)^{2}+\left(m_{3}-n_{3}\right)^{2}\right]}
$$

Untuk mendapatkan bilangan peratusan pakar yang bersetuju, kaedah yang digunakan adalah merujuk kepada bilangan peratusan bagi setiap item yang mendapat nilai threshold, $d \leq 0.2$ daripada setiap pakar. Namun, jika item tidak mencapai 75\%, pusingan kedua Delphi perlu dilakukan.

Untuk mendapatkan nilai purata skor fuzzy pula, pengiraan dan penentuan nilai skor fuzzy boleh menggunakan pilihan rumus defuzzification berikut, yang mana $m_{1}, m_{2}$ dan $m_{3}$ adalah purata respons. Nilai skor ini juga dapat menentukan keutamaan atau kedudukan item bagi menunjukkan urutan kepentingan suatu pemboleh ubah dan sub pemboleh ubah. Untuk kajian ini, pengkaji menggunakan formula yang pertama.

$$
\begin{aligned}
& A_{\max }=\frac{1}{3} \times\left(m_{1}+m_{2}+m_{3}\right) \\
& A_{\max }=\frac{1}{4} \times\left(m_{1}+2 m_{2}+m_{3}\right) \\
& A_{\max }=\frac{1}{6} \times\left(m_{1}+4 m_{2}+m_{3}\right)
\end{aligned}
$$


DOI: https://doi.org/10.47405/mjssh.v5i4.389

\section{Dapatan Dan Perbincangan}

Jadual 3: Nilai threshold bagi setiap komponen KSE

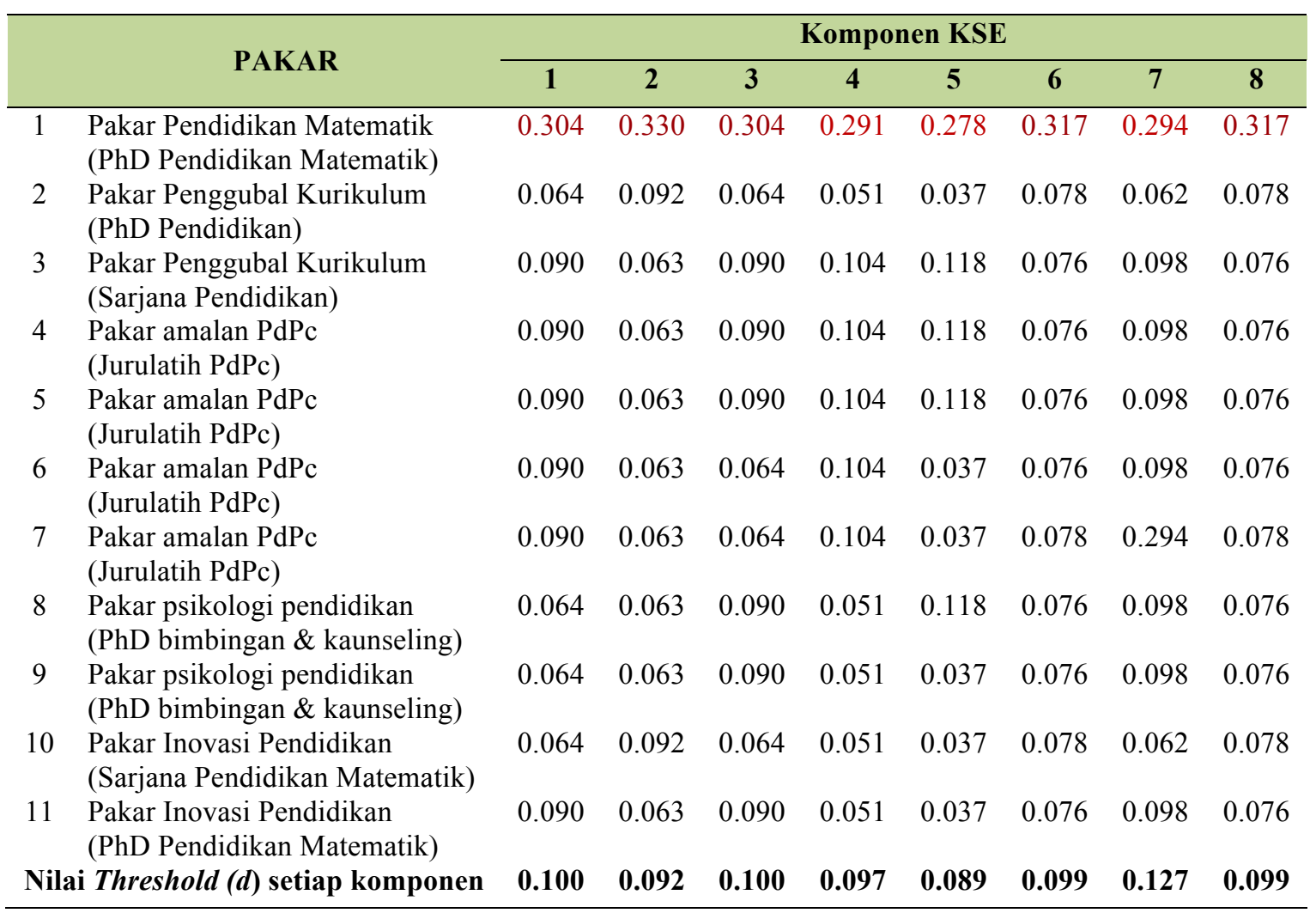

Jadual di atas menunjukkan nilai threshold bagi setiap item oleh setiap pakar. Walaupun 'Pakar 1' memberikan maklum balas yang menjadikan nilai threshold agak tinggi, namun, secara keseluruhan, nilai threshold bagi setiap komponen adalah menepati syarat fuzzy, iaitu di bawah 0.2 Menurut Cheng $\&$ Lin (2002) jika nilai threshold, $d \leq 0.2$, maka, kesemua pakar telah dianggap mencapai persetujuan.

Jadual 4: Nilai threshold, peratusan kesepakatan kumpulan pakar, skor fuzzy dan keutaman bagi setiap komponen KSE

\begin{tabular}{|c|c|c|c|c|c|c|c|c|c|}
\hline \multirow[b]{2}{*}{ Bil } & \multirow[b]{2}{*}{ Item / Elemen } & \multicolumn{2}{|c|}{$\begin{array}{c}\text { Syarat Triangular Fuzzy } \\
\text { Numbers }\end{array}$} & \multicolumn{4}{|c|}{$\begin{array}{c}\text { Syarat Defuzzification } \\
\text { Process }\end{array}$} & \multirow{2}{*}{ 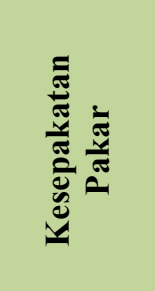 } & \multirow{2}{*}{ 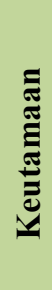 } \\
\hline & & $\begin{array}{l}\text { Nilai } \\
\text { Threshold, } \\
\quad \text { d }\end{array}$ & $\begin{array}{c}\text { Peratus } \\
\text { Kesepakatan } \\
\text { Kumpulan } \\
\text { Pakar, \% }\end{array}$ & m1 & $\mathbf{m} 2$ & m3 & $\begin{array}{c}\text { Skor } \\
\text { Fuzzy } \\
(A)\end{array}$ & & \\
\hline 1 & $\begin{array}{l}\text { Kompetensi } \\
\text { Kesedaran Kendiri }\end{array}$ & 0.100 & $90.91 \%$ & 0.791 & 0.936 & 0.991 & 0.906 & TERIMA & 4 \\
\hline 2 & $\begin{array}{l}\text { Kompetensi } \\
\text { Pengurusan Diri }\end{array}$ & 0.092 & $90.91 \%$ & 0.827 & 0.955 & 0.991 & 0.924 & TERIMA & 1 \\
\hline 3 & $\begin{array}{l}\text { Kompetensi } \\
\text { Kesedaran Sosial }\end{array}$ & 0.100 & $90.91 \%$ & 0.791 & 0.936 & 0.991 & 0.906 & TERIMA & 4 \\
\hline 4 & $\begin{array}{l}\text { Kompetensi } \\
\text { Tanggungjawab } \\
\text { Peribadi }\end{array}$ & 0.097 & $90.91 \%$ & 0.773 & 0.927 & 0.991 & 0.897 & TERIMA & 7 \\
\hline 5 & $\begin{array}{l}\text { Kompetensi } \\
\text { Kemahiran }\end{array}$ & 0.089 & $90.91 \%$ & 0.755 & 0.918 & 0.991 & 0.888 & TERIMA & 8 \\
\hline
\end{tabular}


Malaysian Journal of Social Sciences and Humanities (MJSSH), Volume 5, Issue 4, (page 41 - 55), 2020 DOI: https://doi.org/10.47405/mjssh.v5i4.389

6 \begin{tabular}{lccccccccc} 
Berhubungan & Kompetensi \\
Tanggungjawab & 0.099 & $90.91 \%$ & 0.809 & 0.945 & 0.991 & 0.915 & TERIMA & 2 \\
7 & $\begin{array}{l}\text { Membuat Keputusan } \\
\text { Kompetensi Sikap } \\
\text { Berorientasikan }\end{array}$ & 0.127 & $81.82 \%$ & 0.791 & 0.927 & 0.982 & 0.900 & TERIMA & 6 \\
8 & $\begin{array}{l}\text { Matlamat } \\
\text { Kompetensi } \\
\text { Berfikiran Optimistik }\end{array}$ & 0.099 & $90.91 \%$ & 0.809 & 0.945 & 0.991 & 0.915 & TERIMA & 2 \\
\hline
\end{tabular}

Data dalam jadual 4 di atas pula menunjukkan suatu rumusan bahawa kesemua pakar bersepakat menerima kesemua komponen yang dicadangkan. Seperti yang nyatakan di atas, ini ditunjukkan dengan ketiga-tiga syarat fuzzy dipenuhi, iaitu nilai threshold di bawah atau sama dengan 0.2 (Cheng \& Lin, 2002), peratusan kesepakatan pakar melebihi 75\% (Chu \& Hwang, 2008), dan skor fuzzy melebihi 0.5 (Tang \& Wu, 2010). Daripada skor fuzzy, juga telah memberikan senarai keutamaan terhadap kelapan-lapan kompetensi yang dicadangkan. Senarai keutamaan memberikan maksud bahawa kompetensi yang mempunyai nilai skor fuzzy yang lebih tinggi adalah lebih penting dan diutamakan dalam mencapai matlamat kompetensi sosial dan emosional berbanding kompetensi yang mempunyai nilai skor fuzzy yang lebih rendah dalam konteks pengajaran matematik sekolah menengah.

Dalam kelapan-lapan kompetensi sosial dan emosional, kompetensi pengurusan diri merupakan komponen yang paling utama dalam konteks pengajaran matematik dengan skor fuzzy, $A=0.924$. Ini diikuti dengan komponen tanggungjawab membuat keputusan dan komponen berfikiran optimistik yang berdasarkan analisis KFD mendapat skor fuzzy yang serupa, iaitu 0.915. Dapatan juga menunjukkan komponen kesedaran kendiri dan komponen kesedaran sosial mendapat skor fuzzy yang sama, iaitu 0.906 dan menjadi keutamaan yang seterusnya. Tiga komponen terakhir adalah kompetensi sikap berorientasikan matlamat $(A=0.900)$, kompetensi tanggungjawab peribadi $(A=0.897)$ dan kompetensi kemahiran berhubungan $(\mathrm{A}=0.888)$. Secara keseluruhan, kesemua kompetensi mendapat nilai threshold yang tinggi, iaitu melebihi 0.089 dan kesepakatan pakar sehingga $90.91 \%$. Ini menunjukkan kesemua pakar memberikan kesepakatan tinggi untuk kesemua kompetensi.

Justeru, berdasarkan data dalam jadual kesepakatan pakar komponen KSE berdasarkan analisis KFD, keutamaan kompetensi KSE dalam modul pengajaran matematik sekolah menengah dipersembahkan dalam model berikut:

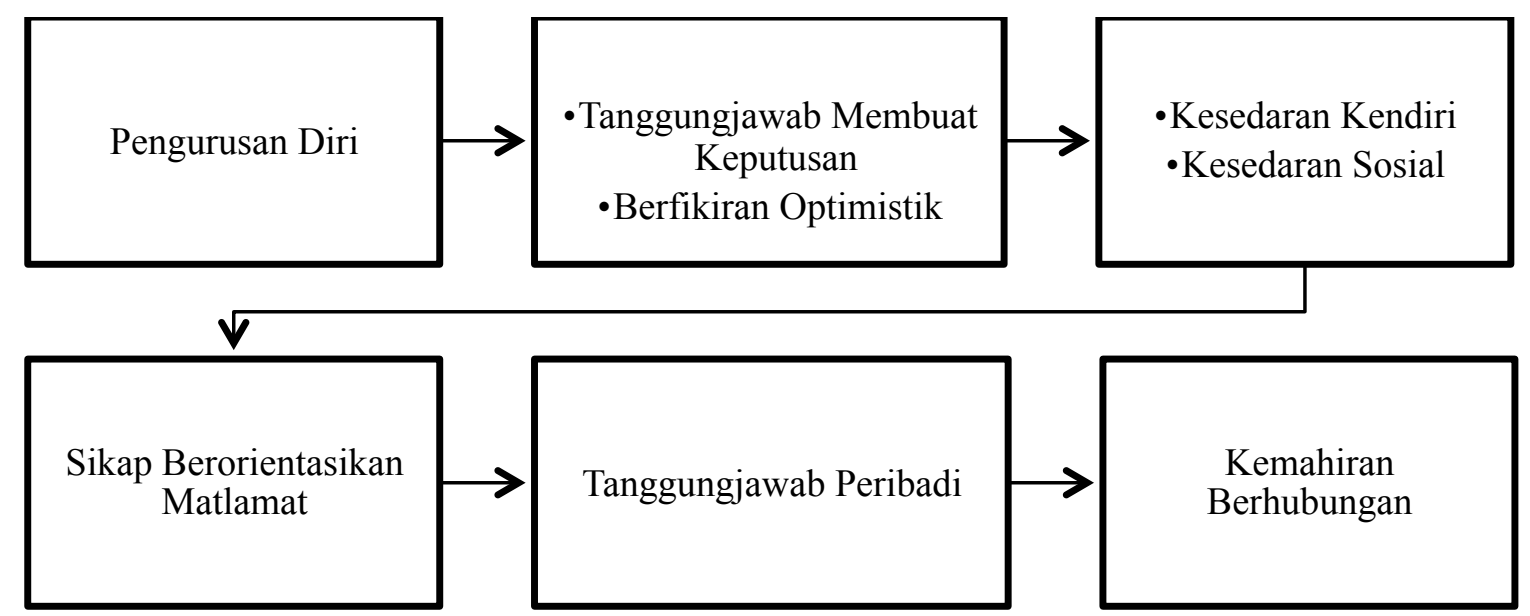

Rajah 4 Model keutamaan kompetensi sosial dan emosional

Jika disorot dalam dapatan kajian literatur dan dapatan analisis kaedah fuzzy delphi, jelas menunjukkan bahawa kesemua pakar bersepakat menerima kelapan-lapan kompetensi sosial dan emosional sebagai kompetensi yang sesuai dijalankan dalam persekitaran sekolah menengah di Malaysia bagi pengajaran 
matematik. Ini juga menunjukkan bahawa elemen penting dalam model CASEL (2017), model DESSA (2018), model ESCI (2011), model 'The Big Five' (1999) dan model OECD (2018) yang sifatnya universal boleh dirungkai sebagai asas dalam menyenaraikan kompetensi sosial dan emosional dalam konteks pengajaran matematik.

Kompetensi kesedaran kendiri penting sebagai dinding pertahanan kepada murid dalam mengenal dan mengiktiraf keupayaan dan batasan diri mereka termasuk emosi diri mereka sendiri (Payton et al., 2000b). Ini disokong oleh Ferguson (2014) dan Shanker (2014) yang menjelaskan risiko kesihatan mental, gangguan dalaman dan luaran, dan lain-lain kesukaran pembelajaran yang akhirnya menjadikan keperluan kepada kompetensi pengurusan diri sebagai turut berkait dan penting untuk murid mengendalikan cabaran harian yang akhirnya bertindak dalam mengawal emosi walaupun dalam keadaan sukar. Dalam konteks pengajaran matematik, kemahiran ini mempunyai implikasi penting untuk terus memotivasikan diri murid dalam menggunakan strategi pembelajaran yang sesuai.

Selain faktor motivasi dalaman, motivasi luaran juga terkait dengan orang lain di sekeliling murid. Justeru, kompetensi kesedaran sosial menjadi turut penting dalam menjadi seorang murid yang memahami sesuatu daripada perspektif pihak ketiga, sama ada persamaan atau perbezaan (CASEL 2013; Payton et al. 2000b). Ini pastinya berkait dengan kompetensi kemahiran berhubungan yang membolehkan murid menjaga hubungan yang sihat dengan orang lain.

Dalam konteks pengajaran dan pembelajaran, murid yang mempunyai kompetensi kesedaran sosial dan kemahiran berhubungan mampu menghargai kepelbagaian dalam tugasan yang bersifat kolaboratif dan koperatif. Ini selaras dengan laporan World Economic Forum (2016) yang mana dalam konteks set kemahiran abad ke-21 (PAK-21), menyenaraikan sepuluh kemahiran penting pada tahun 2020. Antaranya adalah kemahiran pengurusan manusia, kemahiran menyelaras dengan orang lain dan kemahiran berunding. Kemahiran ini juga seiring dengan profil kemenjadian murid KPM iaitu 'prihatin', 'mahir berkomunikasi' dan 'kerja sepasukan' (Bahagian Pembangunan Kurikulum, 2016a, 2016b, 2018).

Selain itu, dalam kajian ini, terdapat dua kompetensi yang berkait dengan soal tanggungjawab. Dua kompetensi tersebut adalah kompetensi tanggungjawab dalam membuat keputusan, dan kompetensi tanggungjawab peribadi. Dalam senarai WEF 2016 di atas, kemahiran membuat keputusan, juga disenaraikan sebagai kemahiran penting untuk dikuasai dalam tahun 2020 (World Economic Forum, 2016). Kompetensi ini juga selaras dengan salah satu profil murid yang dihasratkan KPM bagi memaknakan kemenjadian murid, iaitu sikap 'berprinsip'. Sikap 'berprinsip' ini dijelaskan sebagai murid yang "berintegriti dan jujur, kesamarataan, adil dan menghormati maruah individu, kumpulan dan komuniti. Murid ini bertanggungjawab atas tindakan, akibat tindakan serta keputusannya." (Bahagian Pembangunan Kurikulum 2013a dan 2016b).

Dua kompetensi yang terakhir yang disepakati bersama panel pakar dan selari dengan kajian kepustakaan adalah kompetensi sikap berorientasikan matlamat, dan kompetensi berfikiran optimistik. Kajian SSES daripada OECD (2018) mengkategorikan kompetensi sikap berorientasikan matlamat dalam sub-domain keberhematan (conscientiousness) yang berperanan sebagai motivasi bagi kawalan kendiri dan faktor ketekunan dalam mencapai kejayaan, seperti yang dinyatakan Noftle dan Robins (2007), khususnya dalam konteks pencapaian akademik pada peringkat sekolah menengah dan kolej.

Sikap optimistik pula penting bagi terus menyokong murid dalam usaha mencapai kejayaan. Kemahiran ini membolehkan murid tahan kepada tekanan, dan mengawal emosi apabila menghadapi cabaran. Maka, dalam konteks pembelajaran di sekolah, kompetensi berfikiran optimistik dapat membantu menjadi pendinding murid daripada terjebak dengan masalah disiplin disebabkan pengaruh kawan, perasaan ingin tahu, tekanan jiwa dan juga disebabkan semata-mata mahu berseronok (Institut Kesihatan Umum 2018; Agensi Anti Dadah Kebangsaan 2018) 


\section{Implikasi dan Rumusan}

Intervensi berkaitan pembangunan kemahiran sosial dan emosional telah banyak dijalankan di pelbagai negara. Misalnya, laporan kualitatif kajian-kajian kes yang bersifat longitudinal dikeluarkan Fundacion Botin (2013) dan OECD (2015) telah menunjukkan bahawa terdapat keberkesanan impak dan kepentingan PSE dalam membantu murid sehingga dewasa, daripada aspek pendidikan, pasaran pekerjaan, dan penghasilan sosial. Walau bagaimanapun, tidak banyak kajian berkaitan PSE di Malaysia.

Dalam konteks kurikulum kebangsaan, penerapan PSE disentuh secara eksplisit menerusi Pendidikan Kesihatan, Pendidikan Moral dan Pendidikan Islam. Selain itu, terdapat penerapan PSE melalui elemen Kelestarian Global yang mana menggunakan pendekatan merentas kurikulum khususnya dalam mata pelajaran Sains dan Geografi (Bahagian Pembangunan Kurikulum, 2016a). Walau bagaimanapun, masih kurang pendekatan PSE dalam mata pelajaran matematik secara langsung dan eksplisit. Maka, kajian ini mengisi kesenjangan tersebut. Ini selaras dengan kenyataan Kleickmann et al. (2013) bahawa pengetahuan pedagogi berkaitan kandungan merupakan kompetensi penting yang memberi kesan kepada peningkatan pencapaian murid.

Kajian ini memberikan pengetahuan kepada penggubal kurikulum matematik dan guru-guru matematik, tentang kompetensi sosial dan emosional (KSE) dan turutan keutamaannya dalam konteks pengajaran matematik sekolah menengah. Pengetahuan tentang KSE merupakan satu aspek penting yang perlu dititikberatkan bagi menentukan kompetensi sosial dan emosional yang diharapkan dalam sesi pengajaran dan pembelajaran matematik dalam bilik darjah. Ini sekali gus memberikan implikasi penting kepada amalan pengajaran matematik dalam bilik darjah iaitu keupayaan untuk menerapkan bersama objektif pembelajaran khusus berkaitan kompetensi sosial dan emosional.

Seterusnya, membantu murid meningkatkan kecerdasan emosi dan sosial dengan erti mengekalkan hubungan intra personal dan inter personal yang positif, merasai dan menunjukkan empati dengan orang lain, menentukan dan berusaha untuk mencapai tujuan positif, serta membuat keputusan yang bertanggungjawab dalam kehidupan harian murid (CASEL 2017; Charles A. Dana Center dan CASEL 2016; O'Conner et al. 2017). Oleh itu, dapat dirumuskan bahawa kajian ini berupaya mengisi kesenjangan dalam aspek pengetahuan pedagogi dalam pendidikan matematik.

Namun, cadangan lanjutan yang boleh dibuat selepas ini adalah membangunkan modul pengajaran atau pembelajaran matematik pula. Modul pengajaran atau pembelajaran ini boleh menjuruskan kepada kompetensi-kompetensi tertentu yang bersesuaian ataupun tajuk-tajuk tertentu dalam kurikulum matematik tingkatan tertentu. Ini bakal membina satu wacana baharu pendidikan sosial dan emosional dalam konteks mata pelajaran matematik, dan mungkin dikembangkan dalam lain-lain mata pelajaran bidang sains, teknologi, kejuruteraan dan matematik (STEM).

Sebagai penutup, pembelajaran sosial dan emosional (PSE) merupakan pembelajaran yang sangat penting dalam meningkatkan kompetensi murid menguruskan emosi, meningkatkan perhubungan yang positif serta membina persekitaran yang mana nilai kemanusiaan menjadi faktor penting dalam menghadapi cabaran masa hadapan. Kajian juga menunjukkan bahawa KSE boleh diterapkan dalam pengajaran matematik seterusnya memberikan harapan PSE dalam lain-lain mata pelajaran STEM.

\section{Penghargaan}

Kajian adalah sebahagian daripada projek Kementerian Pendidikan Malaysia bertajuk: $B 40$ Households' Wellbeing Through Education: Vocational Education And Training, Health \& STEM di bawah geran penyelidikan MRUN-2019-001/1 yang diketuai oleh YBhg. Prof. Dr. Ruhizan Mohammad Yasin 


\section{Rujukan}

Agensi Anti Dadah Kebangsaan. (2018). Statistik Dadah: Jumlah Penagih yang Dikesan Mengikut Sebab Guna Dadah.

Astro Awani. (2018). Ponteng sekolah catat rekod tertinggi salah laku disiplin 2017 | Astro Awani. Astro Awani, 2. http://www.astroawani.com/berita-malaysia/ponteng-sekolah-catat-rekodtertinggi-salah-laku-disiplin-2017-171057

Bahagian Pembangunan Kurikulum. (2013). Inisiatif Kemahiran Berfikir Aras Tinggi (KBAT) Di Sekolah. Kementerian Pendidikan Malaysia.

Bahagian Pembangunan Kurikulum. (2016a). Buku Penerangan Kurikulum Standard Sekolah Menengah (KSSM). Kementerian Pendidikan Malaysia.

Bahagian Pembangunan Kurikulum. (2016b). Buku Penerangan Kurikulum Standard Sekolah Rendah (Semakan 2017). Kementerian Pendidikan Malaysia.

Bahagian Pembangunan Kurikulum. (2016c). Standard Kurikulum Matematik KSSR. Kementerian Pendidikan Malaysia.

Bahagian Pembangunan Kurikulum. (2018). Kurikulum Standard Sekolah Menengah Matematik DSKP Tingkatan 4. Kementerian Pendidikan Malaysia.

Barbalet, J. M. (1998). Emotion, Social Theory and Social Structure: A Macrosociological Approach. Cambridge: Cambridge University Press. https://doi.org/10.1017/CBO9780511488740

Bericat, E. (2016). The sociology of emotions: Four decades of progress. Current Sociology, 64(3), 491-513. https://doi.org/10.1177/0011392115588355

Berita Harian. (2018, June 30). Kementerian Pendidikan perlu kekang gejala buli. Berita Harian. https://www.bharian.com.my/berita/nasional/2018/06/443429/kementerian-pendidikan-perlukekang-gejala-buli

Boyatzis, R., \& Goleman, D. (2017). Emotional and Social Competency Inventory: Research Guide and Technical Manual (Version 17). Korn Ferry.

CASEL. (2013). CASEL Guide: Effective Social and Emotional Learning Programs: Preschool and Elementary School Edition. Collaborative for Academic, Social and Emotional Learning. CASEL.

CASEL. (2017). Five Core Competencies of Social and Emotional Learning. CASEL. http://www.casel.org/core- competencies/

Charles A. Dana Center, \& CASEL. (2016). Integrating Social and Emotional Learning and the Common Core State Standards for Mathematics: Making the Case. https://doi.org/10.13140/RG.2.2.31273.44642

Cheng, C.-H., \& Lin, Y. (2002). Evaluating the best main battle tank using fuzzy decision theory with linguistic criteria evaluation. European Journal of Operational Research, 142(1), 174-186. https://doi.org/10.1016/S0377-2217(01)00280-6

Chu, H. C., \& Hwang, G. J. (2008). A Delphi-Based Approach to Developing Expert Systems With the Cooperation of Multiple Experts. Expert Systems with Applications, 34(4), 2826-2840. https://doi.org/10.1016/j.eswa.2007.05.034

Cohen, J. (1999). Educating Minds and Hearts: Social Emotional Learning and the Passage into Adolescence. Teachers College Press.

Cohen, J. (2001). Social and emotional education: Core concepts and practices. In Caring classrooms/intelligent schools: The social emotional education of young children. Teachers College Press.

Devereux Student Strengths Assessment (DESSA). (2018). The DESSA SEL Inventory: A StrengthBased Approach to Promoting Positive Student Behavior. https://www.powerschool.com/wpcontent/uploads/2020/03/Whitepaper-The-DESSA-SEL-Inventory-v1.1.pdf

Elias, M. (2016). How to Implement Social and Emotional Learning at Your School. In Handbook of Social and Emotional Learning: Research and Practice (pp. 2-7). Guilford Press. https://www.edutopia.org/blog/implement-sel-at-your-school-elias-leverett-duffell-humphreystepney-ferrito

Elias, M. J. (2006). The Connection Between Academic and Social-Emotional Learning. The Fundamental Connection of Sel/Ei, Academic Performance, and the Process of Learning, 4-14. https://doi.org/10.2307/1593632 
Elias, M. J., Zins, J., \& Weissberg, R. P. (1997). Promoting Social and Emotional Learning: Guidelines for Educators. Association for Supervision and Curriculum Development. www.ascd.org

Ferguson, B. (2014). Measuring What Matters: Physical and Mental Health in Schools. http://peopleforeducation.ca/wp-content/uploads/2017/06/MWM-health-summary.pdf

Fundacion Botin. (2013). Social and Emotional Education. An International Analysis Fundación Botín Report 2013. Fundacion Botin.

Gagné, F. (1998). A Proposal for Subcategories Within Gifted or Talented Populations. Gifted Child Quarterly. https://doi.org/10.1177/001698629804200203

Goleman, D. (1998). The Emotionally Competent Leader. The Healthcare Forum Journal, 41(2), 3638.

Goleman, D. D. (1995). Emotional Intelligence: Why it Can Matter More Than IQ For Character, Health and Lifelong Achievement. Bantam Books. https://doi.org/10.1016/S09621849(05)80058-7

Institute for Public Health. (2018). National Health and Morbidity Survey (NHMS) 2017: Key findings from the Adolescent Health and Nutrition Surveys (Issue April).

John, O. P., \& Srivastava, S. (1999). The Big-Five Trait Taxonomy: History, Measurement, and Theoretical Perspectives. In L. . Pervin \& O. P. John (Eds.), Handbook of Personality: Theory and Research (Vol. 2, pp. 102-138). Guilford Press. https://doi.org/10.1525/fq.1998.51.4.04a00260

Kleickmann, T., Richter, D., Kunter, M., Elsner, J., Besser, M., Krauss, S., \& Baumert, J. (2013). Teachers' Content Knowledge and Pedagogical Content Knowledge. Journal of Teacher Education, 64(1), 90-106. https://doi.org/10.1177/0022487112460398

L\&T Direct, \& The McClelland Center for Research and Innovation Hay Group. (2011). Emotional and Social Competency Inventory (ESCI): A User Guide For Accredited Practioners (Issue Jun). Hay Group. http://www.eiconsortium.org/pdf/ESCI_user_guide.pdf

Lee, M. ., Yeo, K. ., \& Hadijah, J. (2015). Developing Discipline among Students through SocialEmotional Learning: A New Model to Prevent and Reduce Behavior Problems. Journal of Education and Vocational Research, 6(2), 80-90.

M. Jamil, M. R., Siraj, S., Hussin, Z., Mat Noh, N., \& Sapar, A. A. (2017). Pengenalan Asas Kaedah Fuzzy Delphi Dalam Penyelidikan Reka Bentuk Pembangunan (M. R. M. Jamil (ed.)). Minda Intelek Agency.

Madlan, L., Asnawi, A. A., Seok, C. B., \& Mutang, J. A. (2017). Profil Kecerdasan Emosi Sosial Dalam Kalangan Pelajar Sekolah. Jurnal Psikologi Dan Kesihatan Sosial (JPsiKS), 1, 13-22.

Marchesi, A. G., Cook, K., \& ICF International. (2012). Social and Emotional Learning As A Catalyst For Academic Excellence. https://files.eric.ed.gov/fulltext/ED532586.pdf

Noftle, E. E., \& Robins, R. W. (2007). Personality Predictors of Academic Outcomes: Big Five Correlates of GPA and SAT Scores. Journal of Personality and Social Psychology, 93(1), 116. https://doi.org/10.1037/0022-3514.93.1.116

Noriah, M. I. (2019). Memupuk Kepintaran Pelajar Pintar dan Berbakat, Peranan dan Cabaran Kaunselor. Penerbit Universiti Kebangsaan Malaysia. http://ukmpress.ukm.my

O'Conner, R., De Feyter, J., Carr, A., Luo, J. L., Romm, H., \& ICF International. (2017). A Review Of The Literature On Social and Emotional Learning For Students Ages 3-8: Characteristics Of Effective Social And Emotional Learning Programs (part 1 of 4). Institute of Education Science, US Department of Education, Regional Educational Laboratory at ICF International.

OECD. (2015). Skills for Social Progress: The Power of Social and Emotional Skills. OECD Skills Studies, OECD Publishing. https://doi.org/http://dx.doi.org/10.1787/9789264226159-en

OECD. (2018). Social and Emotional Skills: Well-being, Connectedness and Success. OECD Publishing. https://www.oecd.org/education/school/UPDATED Social and Emotional Skills Well-being, connectedness and success.pdf (website).pdf

Parlimen Malaysia. (2018). Penyata Rasmi Parlimen Dewan Rakyat Parlimen ketiga belas penggal keenam mesyuarat pertama. In Kerajaan Malaysia (Issue Bil.17).

Payton, J. W., Wardlaw, D. M., Graczyk, P. A., Bloodworth, M. R., Tompsett, C. J., \& Weissberg, R. P. (2000). Social and Emotional Learning: a Framework for Promoting Mental Health and Reducing Risk Behaviors in Children and Youth Collaborative for Academic, Social, and Emotional Learning. Reprinted from the Journal of School Health, 70(5), 179-185. 
DOI: https://doi.org/10.47405/mjssh.v5i4.389

Schonert-Reichl, K. A., \& Hymel, S. (2007). Educating the Heart as Well as the Mind: Social and Emotional Learning for School and Life Success. Education Canada, 47(2), 20-25.

Shanker, S. (2014). Broader Measures of Success: Social/Emotional Learning. In Measuring What Matters. People for Education. https://peopleforeducation.ca/wpcontent/uploads/2017/06/MWM-Social-Emotional-Learning.pdf

Shanmugasundaram, U., \& Mohamad, A. R. (2011). Social and Emotional Competency of Beginning Teachers. Procedia - Social and Behavioral Sciences, 29, 1788-1796. https://doi.org/10.1016/j.sbspro.2011.11.426

Sinar Online. (2017, September 29). KPM mahu sifar masalah disiplin di sekolah. Sinar Online. http://www.sinarharian.com.my/nasional/kpm-mahu-sifar-masalah-disiplin-di-sekolah-1.737047

Stets, J. E., Turner, J. H., \& etc. (2006). Handbooks of Sociology and Social Research; Handbook of the Sociology of Emotions (J. E. Stets \& J. H. Turner (eds.)). Springer.

Tang, C. W., \& Wu, C. T. (2010). Obtaining a Picture of Undergraduate Education Quality: A Voice From Inside the University. Higher Education, 60(3), 269-286. https://doi.org/10.1007/s10734009-9299-5

Zins, J. E., \& Elias, M. J. (2006). Social and emotional learning. In Children's Needs III: Development, Prevention, and Intervention (Issue 1). https://doi.org/10.1037/14615-012 